\title{
Tuberculosis after anti-TNF therapy
}

\author{
Ömer Nuri Pamuk • Salim Dönmez
}

Received: 26 February 2009 / Accepted: 6 March 2009/Published online: 20 March 2009

(C) Clinical Rheumatology 2009

\section{Dear Editor}

We read with interest the recent article by Elbek et al. [1] assessing the risk of tuberculosis in patients treated with anti-TNF therapy. The study reported that tuberculin test positivity in the area of their study was quite frequent $(77.9 \%)$ and that males more frequently had positive tests. It was also reported that, in spite of isoniazid prophylaxis, the development of tuberculosis in two of 240 patients could not be prevented. We want to point out to some major problems in that study.

First of all, it was reported that anti-TNF agents were administered to six patients with systemic sclerosis and one patient with cervical cancer. It was stated that anti-TNF therapy proved to be effective in a few patients with earlystage scleroderma [2]. However, a recent open-label pilot study showed that a 26-week treatment schedule with infliximab in scleroderma patients showed no clear benefit [3]. Therefore, we could not understand why a therapy whose efficacy and safety in scleroderma had not been demonstrated was administered to these patients. It is very important to know the treatment results of these patients because of the contribution it will make to the literature. In addition, the readers should have been informed about the time of diagnosis of cervical cancer in one patient. As already known, malignancy poses a contraindication against anti-TNF therapy in all guidelines.

Ö. N. Pamuk $\cdot$ S. Dönmez

Department of Rheumatology, Trakya University Medical Faculty, Edirne, Turkey

Ö. N. Pamuk $(\bowtie)$

Eski Yildiz Cad. Park Apt., No: 24 Daire:18,

Besiktas-Istanbul, Turkey

e-mail: omernpamuk@yahoo.com
Our previous study about this subject revealed that purified protein derivative test (PPD) was significantly more positive in AS patients than in RA patients [4]. Elbek et al. [1] did not separately indicate the frequencies of PPD positivity in RA and AS groups.

Lastly, it was reported that the study was prospectively designed for a 2-year period. However, the maximum follow-up period was stated to be 66 months. It would be good to know whether the authors initially gathered data about the patients retrospectively and turned the study design into a prospective one later. This question should also be answered.

Disclosures None.

\section{References}

1. Elbek O, Uyar M, Aydın N, Börekçi S, Bayram N, Bayram H et al (2009) Increased risk of tuberculosis in patients treated with antitumor necrosis factor alpha. Clin Rheumatol 28:421426

2. Bargagli E, Galeazzi M, Bellisai F, Volterrani L, Rottoli P (2008) Infliximab treatment in a patient with systemic sclerosis associated with lung fibrosis and pulmonary hypertension. Respiration 75:346-349

3. Denton CP, Engelhart M, Tvede N, Wilson H, Khan K, Shiwen X, et al. (2008) An open-label pilot study of infliximab therapy in diffuse cutaneous systemic sclerosis. Ann Rheum Dis doi:10.1136/ard.2008.096123

4. Köker IH, Pamuk ON, Karlikaya C, Tunçbilek N, Cakir N (2007) A low prevalence of purified protein derivative test positivity in Turkish patients with rheumatoid arthritis. Association with clinical features and HRCT findings. Clin Exp Rheumatol 25:54-59 